International Journal of Applied Linguistics \& English Literature

ISSN 2200-3592 (Print), ISSN 2200-3452 (Online)

Vol. 1 No. 5; September 2012 [Special Issue on General Linguistics]

\title{
Native Breath: Incorporating Linguistically Relevant Pedagogy in the Classroom through Reified Literature
}

\author{
Desiree de Chachula (Corresponding author) \\ The Steinhardt School of Culture, Education and Human Development, New York University \\ 239 Greene Street, New York, NY 10003 \\ E-mail:dv476@nyu.edu
}

Received: 08-07- 2012

Accepted: 25-07- 2012

Published: 03-09- 2012

doi:10.7575/ijalel.v.1n.5p.84

URL: http://dx.doi.org/10.7575/ijalel.v.1n.5p.84

\begin{abstract}
The native breath of linguistic minority students, including speakers of vernaculars and dialects, has traditionally been stifled in classroom ecologies that perpetuate the hegemony of English. A model of linguistically relevant pedagogy is articulated that empowers students both native and nonnative to the Standard to develop cultural competence and critical consciousness towards language. This potentially results in improved native breath valuation and paving the road for improved academic outcomes and facility in learning the societal Standard language as well as gaining tools required in the global age. Drawing from the LIAD (Nero, 2005) and Dialect Awareness (Adger, Wolfram \& Christian, 2006) pedagogical frameworks, this paper proposes ways in which educators can support linguistically relevant pedagogy through the teaching of "canonized" fiction.
\end{abstract}

Keywords: bilingualism, culture, literacy

The language I have learn'ed these forty years,

my native English I must forgo;

and now my tongues use is to me no more

Than an unstringed viol or a harp,

Or like a cunning instrument cased up,

Or, being open, put into his hands

That knows no touch to tune the harmony:

Within my mouth you have engao'ld my tongue

Doubly portcullis'd with my teeth and lips;

And dull unfeeling barren ignorance

Is made my gaoler to attend on me

I am too old to fawn upon a nurse,

Too far in years to be a pupil now:

What is thy sentence then but speechless death,

Which robs my tongue from breathing native breath

-Mowbray, Richard II, Act 1 scene 3 (Shakespeare, W. 1595)

\section{Introduction}

Being banished from England for life by King Richard and being sent to a land where his native language of English is ineffectual, the Duke of Norfolk laments a fate worse than death, a "speechless death" or a life that leaves his native tongue impotent. This speechless death is a reality for many English language learners and dialect speakers who are unable utilize their native language in schools. Students whose first language is not Standard English contend with the suffocation of "native breath" that Shakespeare describes in some classroom ecologies. Native breath constitutes an individual's natural and most expressive language and is where their 
International Journal of Applied Linguistics \& English Literature

ISSN 2200-3592 (Print), ISSN 2200-3452 (Online)

Vol. 1 No. 5; September 2012 [Special Issue on General Linguistics]

voice and identity are grounded. The modern classroom is a medley of learners from diverse cultural and linguistic backgrounds. Yet, only Standard American English (SAE), the high-status language in the US is often legitimized leaving students' rich cultural and linguistic capital unmined resulting in native breath suffocation very much like King Richard. Much has been articulated concerning aligning school culture with students' lived lives (Canagarajah, 2005) and Culturally Relevant Pedagogy (CRP) has made strides in this pursuit (Ladson-Billings, 1995). Yet, linguistically relevant pedagogy has been collapsed into culturally relevant pedagogy and inadequately developed. While it is true that language and culture are inextricable, a pedagogical language focus highlights and reveals the legitimacy of learners' home languages and demystifies the goal and purpose of Academic American English. Moreover, linguistically relevant pedagogy empowers students to string their instruments and harmonize SAE with their native breath.

Linguistically Relevant Pedagogy (LRP) holds at its core the same goals as CRP: "(a) Students must experience academic success; (b) students must develop or maintain cultural competence; and (c) students must develop a critical consciousness through which they challenge the status quo of the current social order" (p. 160, Ladson-Billings, 1995). Academic success in the fulfillment of these goals is not bartered for native breath but rather native breath serves as a vehicle for academic success. Essential to LRP is overtly examining and uncovering the power relations involved in stratifying language status. This is accomplished in LRP by focusing attention on language use in society and linguistic structural features. The tenets of LRP are informed by the field of World Englishes and hold that (a) everyone speaks a dialect of English and the "standard" changes over time (language change theory) (Brutt-Griffler, 2002) (b) dialects are fully developed language systems (Labov, 1973) (c) languages and dialects are in themselves equal but issues of power suppress or encourage language use in specific contexts (Gee, 1995; Leung, Harris \& Rampton, 1997; Blackledge, 2003). LRP is applicable to the wide spectrum of Standard American Academic English learners from English as Additional Language students to Vernacular English Speakers and Generation 1.5 speakers. Dominant language speakers also benefit from LRP as it encourages metalinguistic awareness and the cultural competence that is necessary for negotiation of our global village (Suarez-Orozco, 2003). In his lectures at MOMA on Reconsiderations in a Postmodern, Digital Era, Howard Gardner posits that the mastery and cultivation of sophisticated interpersonal competencies manifested in the ability to interact constructively with those of different cultural and linguistic backgrounds will be the "will be the cornerstone of educational systems in the most successful democracies of the twenty-first century" (2008). Additionally he predicts that societies that "enforce a regime of compulsive monoculturism and compulsive monolingualism" and do not foster hybrid or blended identities manifested in multilingual and transcultural sensibilities will falter under globalization. As it is estimated by the U.S. Census Bureau that $50 \%$ of learners will possess a native breath that is not Standard English by 2050, LRP is, and will become, of increasing relevance having both local and global implications. The use of Linguistically Relevant Pedagogy in the classroom has the potential to improve academic outcomes for all students, particularly those that the achievement gap has marginalized by critically and linguistically unpacking and demystifying the use and purpose of the standard language. Validating a student's native breath and unmasking language attitudes empowers students to use their linguistic repertoires in strategic way. This paper will suggest the utility of LRP through the domains of academic success, cultural competence and critical consciousness and then provide a suggestion for pedagogical implementation of LRP using canonized literature.

\section{Academic Success}

Students' positioning and perception of their native breath valuation in the classroom is a critical determinant of academic success in the dominant target language. Identity construction is an empirically demonstrated factor for academic success (Nasir \& Saxe, 2003). Citing Gardener (1985a), Baker (1925) states, "language attitude is a precursor and determinant of language proficiency and use" (p. 41). Negative native breath attitudes are persuasive in schools, as dialects are often considered incomplete and "lazy" acquisition of the dominant language (Adger, Wolfram \& Christian, 2004) and multilingualism is perceived as a threat to the hegemonic ethos of monolingualism. When the uniform dominant language is insisted upon in classrooms, teachers are "helping reproduce monolinguistic ideologies and linguistic hierarchies" (Canarajah, 2006, p. 587). Smitherman (2003) echoes this sentiment: "The classroom, then is a major player in shaping language attitudes, and those classrooms that are particularly crucial for formation of ideas about language are those on the K-12 level" (Smitherman, 2003, p. 34). The classroom is the most immediate place that language attitudes play out and are promulgated and thus have the potential to perpetuate or change student beliefs. It is there that students solidify their estimation and valuation of their linguistic capital and resulting identity. These factors however are amenable to classroom culture and climate; LRP has the ability to shift "outside" power relations and create 
International Journal of Applied Linguistics \& English Literature

ISSN 2200-3592 (Print), ISSN 2200-3452 (Online)

Vol. 1 No. 5; September 2012 [Special Issue on General Linguistics]

ecology in the classroom that breeds positive native breath positioning. Positive language estimation of students' native breath has been widely reported to facilitate the ease and acquisition of the dominant language by favorably impacting identity formation (Michael- Luna, 2008), self-efficacy (Alverman, 2001), self-confidence (Wolfram \& Shilling-Estes, 1998) and motivation (Shannon, 1995). Additionally, attending to language structures themselves promotes language acquisition as students acquire syntactic and lexical metalinguistic skills through contrastive analysis.

Serious attention to language attitudes should include examinations of features of vernacular and standard dialect. Adger, Wolfram and Christian (2007) contend that thoughtful instruction of Standard English is the reconciliation of the polemic SE debate:

Given societies attitudes, Standard English must be regarded as a necessary tool for success in school and in the workplace and that schools should be held responsible for providing students with that tool. Because attitudes are extremely difficult to change, schools should provide high-quality instruction in Standard English, rather than waiting for social attitudes to be altered. Parents from vernacular-speaking communities typically expect that schools will teach Standard English because they are likely to hold some of the entrenched and unjustified language prejudices found in the society at large. They recognize the instrumental value of Standard English to equip their children with the tools they need for economic success. (p. 99)

LRP nurtures academic success as it promotes the teaching of the "standard" while validating students' linguistic resources and maintaining their cultural capital in a wider educational climate that uses tests to perpetuate the defacto status of English as king. This monolithic ethos, that is disabling the viability of American students international competiveness is tempered via LRP and potentially provides a digital -age- ready global citizen that that is interculturally competent and capable of navigating hybrid identities and linguistic discourses.

\section{Cultural Competence}

LRP proposes an additive way for student to make meaning of their world and others as well as their relationships with others. Fostering LRP provides students with increased capital to compete in the global economy while attending to their sociocultural needs and countering the English hegemony. Bilingual and ESL programs have tended to be reductive (Krashen, 1996), sending the message that the culture that is situated within a language must also be snuffed out. As America in covertly an assimilationist culture, the main unifier and uniformer is language or English. However, as language is identity, a reductive approach to language in the classroom often results in an attrition and marginalization of a student's cultural capital. Colonialism unfortunately has often left this as its legacy. LRP counters this and along with validating students' native breath, also validates their native breadth or the deep and encompassing symbol system -- the rituals, beliefs, values that the signs represent. This native breadth represents students' collective and immediate cultural history and practices beyond language.

Cultural competence then allows awareness, insight, and sensitivity into fellow interlocutors' symbol and sign systems, providing deeper understanding of their own. This competence then becomes not only the understanding of practices but also the language that is used to directly represent them. Hence the utility and manner of language for expressiveness becomes integral to LRP. The notion of "speech communities" and the appropriateness of choosing the best-fit "language" to match the circumstance are critical to the theory. Speech communities are discrete groups of people that use language in distinct ways to suit the expressions of the native breadth of a community. Speech communities are variable within languages and dialects and often include changes in lexicon and at times intonation and syntax. Is this skill to navigate between speech communities that demonstrate the great value in mastering the language of as many communities as one is able. The native breath is as important as the standard as each allows access to the different communities. Canagarajah terms the piloting between languages as a shuttle between speech communities underscoring Siegel's (2006, p. 40) notion that the vernacular should be a bridge to the standard and not an obstacle.

Shuttling, then, and the notion that students are masters of multiple communities gives students access to greater means of expressiveness. For that reason there is "no reason to stigmatize mixing and switching; in fact, these can be exploited for effective language teaching as translation between languages and varieties" (Kachru, p. 31) and demonstrates a sophisticated mastery of linguistic systems.

\section{Critical Consciousness}

Unfortunately, like dialects and vernaculars, code mixing and switching is stigmatized and perceived to be 
International Journal of Applied Linguistics \& English Literature

ISSN 2200-3592 (Print), ISSN 2200-3452 (Online)

Vol. 1 No. 5; September 2012 [Special Issue on General Linguistics]

indicative of an incomplete development of linguistic systems. These incorrect popular perceptions contribute to the deficit approach that plagues linguistic minority students and the pervasive attitudes that another language or dialect is a liability rather than benefit. The societal and cognitive advantages of multilingualism have been well documented and will not be further elaborated here (for a full discussion see: Brutt-Griffler, 2007). One of the best ways to counteract these misinformed entrenched fallacies is to uncover and confront them. Raising student's critical consciousness to contemplate language status, prestige and attitudes empowers and positions students to be authors of their own pronouncements. Delpit (1995) echoes this advocating for an open dialogue concerning power dynamics in the classroom for in doing so she holds students become aware of and hence active and agents in their power positioning. Rather than become passive receptors of the legacy of antiquated and misappropriated language beliefs, LRP empowers students to question the status quo. As language and power are conjoined and entrenched with one another, LRP provides an ideal context for discussions, as it is diaphanous in questioning the notion of a Standard English. Gee (1990) explains this relationship as "any view of literacy is inherently political and in the sense of involving relationships of power around people" (p. 31). Exposing that Standard English is married to a written stable form and mainly designed for institutional purposes (education, administration, business etc.) begins to uncover its utility and dominance. Widdowson furthers this by stating that "its spoken version is secondary, and typically used by those who control these institutions" (1994, p. 380). As language status can be defined as the relative perception of a language to access the intellectual, economic and mobility capital of a speech community, critical consciousness is raised by the understanding and questioning of why and how power is held and perpetuated by the dominant language speakers.

Exploring with students and unveiling issues of language and power provides emancipatory potential (Morgan, 1997) and develops students' critical consciousness. LRP provides a grass roots approach to question and change language attitudes in the classroom and attempts to change "the belief in the inferiority of vernaculars is a major reason for the current educational practice of keeping them out of the classroom, and this practice helps to perpetuate the belief that these vernaculars are inferior" (Siegel, 2006, p. 43). Students become unshackled by the fetters of linguicism and they are allowed the freedom to construct and rebuild truth-based representations of language and empowering their native breath valuation.

Though wider language attitudes are resistant to change, local microsystems are much more amenable. A classroom culture is predominately created by the teacher, and the teacher can promulgate destructive language attitudes or move to eradicate them. Adger, Wolfram \& Christian (2006) account in regards to language dynamics in schools that: "The language context outside of school does not override the language context inside school...if tension between standard and vernacular speakers are high, the vernacular-speaking students have reason to resist the standard variety. If relationships between groups are harmonious and if the vernacular dialect and the associated culture are not devalued in the school and classroom, students may not experience a disjunction in schools in terms of language." (p. 99) It is within a teacher 's power to compose harmony and collaboratively construct with students the value and linguistic capital of learners in their classrooms.

It is this difference as opposed to the deficit position that is the cornerstone of LRP. The remainder of this paper will argue that much of English literature, particularly American literature, is dialect or vernacular literature (Ahmad, 2007) and therefore presents a unique opportunity to engage in incorporating LRP into existing curriculum.

\section{In Practice}

In terms of valuing linguistic diversity in multilingual education, a common contention of educators is that "it is difficult to know what this means in concrete terms and in every day classroom practice"(Sawyer, 2008, p. 94). Teachers are uniformly well intended in instructing students SAE and have an increasing understanding of implementing cultural competence and sensitivity in the classroom. However, instructing to linguistic diversity is more novel and hence unclear. Ways to achieve LRP in the classroom though using existing curricula will be presented in the remainder of this paper.

In the introduction to the anthology Rotten Fiction, a literary anthology of what has often been perceived as "bad" English, Ahmad (2007) reports that over half of the Man Booker Prize Winners over the last twelve years are in a nonstandard English. In fact, as she chronicles those who have written in vernacular, the list is a litany of literary giants: Mark Twain, Alice Walker, F. Scott Fitzgerald, Chaucer, Dante, Shakespeare, Robert Burns, Paul Laurence Dunbar, George Bernard Shaw, Rudyard Kipling, James Joyce, Gertrude Stein, Langston Hughes, Zora Neale Hurston, James Baldwin. With such a list of formidable and diverse authors, "vernacular literature" must be qualified. Ahmad defines it as "composing in linguistic codes that are primarily spoken rather than written, 
International Journal of Applied Linguistics \& English Literature

ISSN 2200-3592 (Print), ISSN 2200-3452 (Online)

Vol. 1 No. 5; September 2012 [Special Issue on General Linguistics]

and also ones that have generally been perceived as having a lower status than Standard English" (p.16). Clearly, vernacular literature is prevalent and currently widely used in classrooms. However, there may be teachable opportunities missed beyond the artistry and narrative of such pieces. Ahmad states that vernacular literature is "anti-institutional by nature" and "challenge the hierarchy implied by 'dialect' versus 'language' or 'standard' versus 'nonstandard,' insisting that the codes they practice be recognized for their strength, coherence and communicative capacity" (p. 17). From a literary standpoint, vernacular writing is completely validated in the artistic community. Yet, there exists a gaping discrepancy between when and where vernacular is legitimized. In the classroom, when spoken by students, vernacular is often corrected with the intention to transform it to the Standard rather than using the vernacular as a scaffold to building the Standard and teaching students how to shuttle between the two. LRP has the power to uncover and rectify these discrepancies within the classroom community.

The teaching of vernacular "canonized" literature is a particularly powerful implementation of LRP as students can meaningfully explore language and subsequent power issues through attending to linguistic forms and patterns in addition to the themes they often espouse. Nero (2005) articulates one such pedagogical framework, the Language, Identity, Awareness and Development (LAID) that provides a detailed blue print of how educators can, "go beyond language as a form, by raising students' investment in, and use and knowledge of language as it correlates with their identities/ affiliations" (p. 203) Two of her pillars of note include, making language itself a central focus of study and raising awareness of language through intensive reflection and exploration.

Similarly, Adger and colleagues (2007) propose general principles for promoting bidialectalism and bilingualism. Among these principles are that an instructional program for teaching standard English must proceed from explicit curricular goals, it should include information on dialect diversity and should reveal systemic differences between standard and vernacular forms (pp. 105-106).

A misconception of teaching vernacular literature to foster LRP is that it is only relevant to secondary education as most "literature" is taught during these years. However, there exists a breath of vernacular literature in the primary grades in both picture and trade books. For example, House on Mango Street by Pam Munoz and Honey I Love by Eloise Greenfield present salient opportunities to explore language structures and dynamics. These works are appropriate for younger learners and their linguistic features are fodder for rich discussion and explication.

\section{Conclusion}

The poet and activist Gloria Anzaldua chronicles the continuum of languages that Chicanos speak: 1. Standard English; 2. Working class and slang English; 3. Standard Spanish; 4. Standard Mexican Spanish; 5. North Mexican Spanish Dialect; 6. Chicano Spanish; 7. Tex- Mex, and 8. Pachuco. It is no wonder that she writes or her "serpents tongue" or her forked duality of language and expression spanning the bridge between Standard English and Standard Spanish. This metaphor is particularly apt in depicting the ideal outcome for linguistic minority students. The serpent is characteristically able to easily maneuver from one environment to the next. Their forked tongue serves their purpose to perceive, understand and explore their environment. Similarly, students should be able to navigate (slither compared to shuttle) through speech communities using their linguistic repertoires to engage fully with their ecologies. LRP advocates for the development of sophisticated linguistic serpents and eschews the perpetuation of powerless linguistic servants.

\section{References}

Adger, C. T., Wolfram, W., \& Christian, D. (2007). Dialects in schools and communities. (2nd ed.). Mahwah,NJ: Lawrence Erlbaum Associates.

Ahmad, D. (2007). (Ed.). Rotten English: A literary anthology. New York \& London: W.W. Norton.

Baker, C. (1992). Attitudes and language. Clevedon: Multilingual Matters.

Blackledge, A. (2003). Imagining a monocultural community: Racialization of cultural practice in educational discourse. Journal of Language, Identity, and Education, 2(4), 331-347.

Brutt-Griffler, J. (2002). World English: A study of its development. Clevedon, England: Multilingual Matters Press.

Brutt-Griffler, J. (2007). Bilingualism and Elearning. In R. Andrews \& C. Haythornthwaite (Eds.), Handbook of

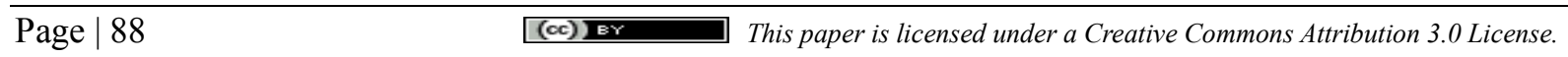


International Journal of Applied Linguistics \& English Literature

ISSN 2200-3592 (Print), ISSN 2200-3452 (Online)

Vol. 1 No. 5; September 2012 [Special Issue on General Linguistics]

Elearning Research, pp. 349-370. London: Sage.

Canagarajah, S. (2005). Critical Pedagogy in L2 Learning and Teaching. In E. Hinkel (Ed.), Handbook of Research in Second Language Teaching and Learning (pp. 931-949). Mahwah, New Jersey: Lawrence Erlbaum Associates.

García, O. \& Menken, K. (2006). The English of Latinos from a plurilingual transcultural angle: Implications for assessment and schools. In S. Nero (Ed.), Dialects, Englishes, creoles, and education (pp. 167-184). Mahwah, NJ: Lawrence Erlbaum Associates.

Gee, J. P. (2000). Discourse and sociocultural studies in reading. In M.L. Kamil, P.B. Mosenthal, P.D. Pearson, \& R. Barr (Ed.), Handbook of reading research (pp. 195-207). Manweh, NJ: Erlbaum.

Kachru, Y. (2006). World Englishes and language education. In S. J. Nero (Ed.),Dialects, Englishes, Creoles and Education (pp. 19- 37). London: Lawrence Erlbaum Associates.

Krashen, S. (1996). Under Attack: The Case Against Bilingual Education. Burlingame CA: Language Education Associates.

Labov, W. (1972). Sociolinguistic Patterns. Philadelphia: University of Pennsylvania Press.

Ladson-Billings, G. (1995). But that's just good teaching! The case for culturally relevant pedagogy. Theory into Practice, 34(3), 159-165.

Ladson-Billings, G (1995). Toward a theory of culturally relevant pedagogy. American Education Research Journal, 35, 465-491.

Leung, C., Harris, R. \& Rampton, B. (1997). The idealised native-speaker, reified ethnicities and classroom realities. TESOL Quarterly, 31(3): 543-60.Michael-Luna, S. (2008). Todos somos Blancos/We are all white: Constructing racial identities through texts. Journal of Language, Identity \& Education, 7(3), 272-293.

Morgan, B. (1997). Identity and intonation: Linking dynamic processes in an ESL classroom. TESOL Quarterly, 31(3), 431-450.

Nasir, N. S., \& Saxe, G. B. (2003). Ethnic and academic identities: A cultural practice perspective on emerging tensions and their management in the lives of minority students. Educational Researcher, 32(5), 14.

Nero, S. J. (2005). Language, identities, and ESL pedagogy. Language and Education, 9(3), 194-211.

Shakespeare, W. (2003). Richard II. London: Nick Hern Books.

Shannon, S. M. (1995). The hegemony of English: A case study of one bilingual classroom as a site of resistance. Linguistics and Education, 7(3), 175-200.

Siegel, J. (2006). Keeping creoles and dialects out of the classroom: Is it justified? In S. J. Nero (Ed.), Dialects, Englishes, Creoles and Education (pp. 19-37). London: Lawrence Erlbaum Associates.

Suárez-Orozco, M. (2000). Everything you ever wanted to know about assimilation but were afraid to ask. Daedalus-Journal of the American Academy of Arts and Sciences, 129(4), 1-30.

U.S. Census Bureau. (2008). U.S. Interim Projections by Age, Sex, Race, and Hispanic Origin: 2000-2050 [Data file]. Retrieved from: http://www.census.gov/ipc/www/usinterimproj/

Wolfram, W., \& Schilling-Estes, N. (1998). Tri-ethnic dialect situations. American English,181-182. 